\title{
Mother and Child Anti-malnutrition Programs as a Part of Mission of European/Christian Values. An Example from Muhuroni Kenya and Condi in Burundi (Research note)
}

D. Kimuli (Daria Kimuli)2,5, T. Rasonyi (Tamas Rasonyi)', H.Selles (Hadjira Selles)2,3, T. Rusnak (Tomas Rusnak)2,3, V. Pazitna (Veronika Pazitna)², I. Adam (Irena Adam)², A. Beresova (Anna Beresova) ${ }^{3}$, M. Fula (Milan Fula)2, M. Komlosi (Maria Komlosi) ${ }^{4}$, Z. Komlosi (Zoltan Komlosi)4, L. Matulnik (Ludmila Matulnik)2, Z. Ondrusova (Zlatica Ondrusova)2, C. Muss (Claus Muss) 3,5

${ }^{1}$ School of Public Health, Semmelweis Medical University Budapest, Hungary

2 Antimalnutrition SEU programs in Condi, Malindi, Eldoret

${ }^{3}$ St. Elizabeth University Tropical Institute, and Inst. of Microbiology, Slovakia

${ }^{4}$ School of Medicine, Comenius University, Bratislava, Slovakia

5 Tropical program SEU in Condi/Republic of Kenya, Republic of Burundi

\section{E-mail address:}

tropicteam@gmail.com

\section{Reprint address:}

Ludmila Matulnik

St. Lesley College

Nove Zamky,

SK

Source: Clinical Social Work and Health Intervention

Pages: $65-67$
Volume: 9

Issue: 4

\section{Reviewers:}

Selvaraj Subramaniam

UMKL, Kuala Lumpur Malaysia

\section{Key words:}

Anti-malnutrition Programs.

\section{Publisher:}

International Society of Applied Preventive Medicine i-gap

CSWHI 2018; 9(4): 65 - 67; DOI 10.22359/cswhi_9_4_09 @ 2018 Clinical Social Work and Health Intervention 


\section{Abstract:}

The Anti-malnutrition Program (AMP) is the most successful program that has been introduced in Sub-Saharan Africa to reduce malnutrition in mothers and children suffering from starvation and irreversible damage to their psychosocial development.

\section{Introduction}

Large natural disasters such as migrant crisis in Myanmar, tsunami in Indonesia, earthquake in Haiti offers opportunity for humanitarian help. In 2018, famine looms across 13 countries in Africa and the Middle East. At least 2.5 million kids are still confronting starvation. (3)

Anti-malnutrition programs launched in 1990s when RUTF (ready to eat therapeutic food) and special milk formulas for fighting malnutrition were introduced for the first time saving millions lives. They are, in fact, the most successful programs introduced to Sub-Saharan Africa to reduce malnutrition in mothers and children suffering from starvation and irreversible damage to their psychosocial development. (1,2) An overview of AMP in SSA as a part of the Mission of European Christian Values is presented.

\section{Overview of anti-malnutrition programs in Africa}

An overview of anti-malnutrition programs in 6 Sub Saharan African countries operated by anti-malnutrition staff of Tropic team of St. Elizabeth University in Kenya, South Sudan, Uganda, Burundi, Lesotho, and Rwanda is described. Programs are operating since 1999 (Kenya); 2000 (S. Sudan); 2004 (Uganda); 2008 (Burundi); 2010 (Rwanda) providing milk powder ("Milk for Mothers and Children") - Muhoroni and Nairobi, general food (wheat) Malindi, Nairobi, for pregnant women in Gordhim (S. Sudan), meat for children ("Goat for taskforce") (Tab 1).

Table 1: Overview of anti-malnutrition programs as example of mission of European values

\begin{tabular}{|l|c|c|c|c|c|c|}
\hline & S. Sudan & Kenya & Uganda & Lesotho & Burundi & Rwanda \\
\hline $\begin{array}{l}\text { General AMP } \\
\text { (children) }\end{array}$ & + & + & - & - & + & + \\
\hline $\begin{array}{l}\text { General AMP } \\
\text { (mother \& } \\
\text { children) }\end{array}$ & + & + & - & - & - & - \\
\hline $\begin{array}{l}\text { Gen. food for } \\
\text { pregnant }\end{array}$ & + & - & - & - & - & - \\
\hline $\begin{array}{l}\text { Meat program } \\
\text { "'goat taskforce" }\end{array}$ & - & - & + & - & + & - \\
\hline $\begin{array}{l}\text { "Milk for children } \\
\text { and mothers" } \\
\text { program }\end{array}$ & - & + & - & - & - & - \\
\hline $\begin{array}{l}\text { Vitamins }+ \\
\text { elements for } \\
\text { mothers }\end{array}$ & + & + & - & + & - & - \\
\hline
\end{tabular}




\section{Conclusion}

Anti-malnutrition programs are crucial for mother and child's health and school prosperity in Sub-Saharan Africa where about 40 million children and mothers are starving. Apart of the World Bank, Global Fund and FAO (Rome) NGOs in all EU and US should meet together.

\section{References}

1. RTI decreased after introduction of RDTs in rural areas of Kenya. (2017) Neuroendocrinology Letters. 2017 Nov; 38(Suppl1):27-29. PubMed PMID: 29200251.

2. BALUCHOVA B, MAMOVA A (2017) The role of implementation and communication of MANTRA Water, sanitation and hygiene program in improving public health in Odisha state (India) Neuroendocrinology Letters 2017; 38(Suppl.1):35-39.

3. CLASEN T, BOISSON S, ROUTRAY P, TORONDEL B, BELL M, CUMMING O, ENSINK J, FREEMAN M, JENKINS M et al (2014) Effectiveness of a rural sanitation program on diarrhea, soil-transmitted helminth infection, and child malnutrition in Odisha, India: a cluster-randomized trial. The Lancet Global Health, Vol. 2, Issue 11, 2014, Pages e645-e653, ISSN 2214-109X, https://doi.org/10.1016/S2214109X(14)70307-9. 